\title{
Psycholinguistic Study of Functioning of Cognitions and Metacognitions on the Levels of Social Intelligence
}

\section{Психолінгвістичне вивчення функціонування когніцій і метакогніцій на рівнях соціального інтелекту}

Eduard Ivashkevych ${ }^{1}$

Dr. in Psychology,

Professor
Едуард Івашкевич ${ }^{1}$

доктор психологічних наук, професор

E-mail: natasha1273@ukr.net orcid.org/0000-0003-0376-4615

Researcher ID: V-8872-2018

\begin{abstract}
Alla Yatsjuryk ${ }^{2}$ Ph.D. in Psychology, Assistant Professor
\end{abstract}

\section{Алла Яцюрик ${ }^{2}$}

кандидат психологічних наук, доцент

\section{E-mail: yatsiuryk.a@gmail.com orcid.org/0000-0003-3933-8503 \\ Researcher ID: F-3174-2019}

${ }^{1}$ Rivne State University of the Humanities, Department of General Psychology and Psychological Diagnostics $\triangle 12$, Stepan Bandera Str., Rivne, Ukraine, 33000
${ }^{1}$ Рівненський державний гуманітарний університет, кафедра загальної психології та психодіагностики $\checkmark$ вул. Степана Бандери, 12, м. Рівне, Україна, 33000 
${ }^{2}$ International Economic and Humanitarian University named after Academician Stepan Demyanchuk,

Department of Psychology

4, Stepan Demyanchuk Str., Rivne, Ukraine, 33000
2 Міжнародний економікогуманітарного університет імені академіка Степана Дем'янчука, кафедра психології

вул. Степана Дем'янчука, 4, м. Рівне, Україна, 33000

Original manuscript received September 19, 2018

Revised manuscript accepted January 15, 2019

\section{ABSTRACT}

The article states that social intelligence in psychology is seen as the ability of a person to understand correctly his/her own behavior and the behavior of other people in the society. This ability is very necessary for a person to have an effective interpersonal interaction and successful social adaptation. Social intelligence implements the functioning of cognitive processes associated with the reflection of a person as a partner in the processes of communication and activities. The main function of social intelligence is to predict the behavior of others.

The authors of the article consider the concept of "intelligence» in the broad and narrow senses. In a broad meaning of "intelligence» it is only one intelligence, the intellectual sphere of the person in general. In this sense, the intelligence of a person can be described as a hierarchical system that has several levels. The first level is the level of functioning of cognitions. The second level of intelligence is the level of metacognitions. The third level of intelligence amplifies the characteristics of both the first and the second levels, while intellectual activity is carried out mainly at an unconscious level, a level that approximates a person to use of automated skills and abilities. The next, the fourth level, is the level of meta-intellectual activity, which explodes the creative achievements of the person.

It was proved that each type of intelligence contained some abilities of the person to perform a certain type of the activity. Guided by the narrow sense of understanding the word «intelligence», it was determined: social intelligence; technical intelligence; artistic intelligence; information intelligence.

It was described the empirical research which was organized in different regions of Ukraine (the participants of this research were teachers and directors from preschool educational establishments). The results having been received in this research proved that the respondents of all groups have the results which show the advantage of average indicators of their ability to understand the meanings of nonverbal expressions and the meaning of the expression, depending on a social context. This may be due to the fact that these abilities are formed in the immediate process of communication and to a large extent depend on the conditions of the life of the subjects, at the first place - on the conditions of their professional activity, means and methods of professional activity of teachers of preschool educational establishments.

Key words: the social intelligence, cognitions, metacognitions, meta-intellectual activity, technical intelligence; artistic intelligence; information intelligence. 


\section{Introduction}

Social intelligence in psychology is seen as the ability of a person to understand correctly his/her own behavior and the behavior of other people in the society. This ability is very necessary for a person to have an effective interpersonal interaction and successful social adaptation. Social intelligence implements the functioning of cognitive processes associated with the reflection of a person as a partner in the processes of communication and activities. The main function of social intelligence is to predict the behavior of others.

We consider the concept of «intelligence» in the broad and narrow senses. If we talk about the broad meaning of «intelligence», we mean about only one intelligence, the intellectual sphere of the person in general. In this sense, the intelligence of a person can be described as a hierarchical system that has several levels. The first level is the level of functioning of cognitions, to which psychologists refer the main psychical processes (sensation, perception, memory, attention, which, in turn, «control» the course of cognitive activity), as well as thinking and imagination, speech and dialogical interaction (Collins, 2014; Smulson, 2003; Zasekina, 2006). The second level of intelligence is the level of metacognitions (metacognitive integrators, "secondary» mental processes), among which the main ones are intellectual initiation (self-statement of the problem), reflection, decentralization, intellectual strategies and abilities (abilities and competences), as well as metacognitive monitoring, intuition, intellectual atheist (values, meanings) (Tillman \& Louwerse, 2018). The first and the second levels of intelligence, in our opinion, are fully understood by the person who carries out intellectual activity. The third level of intelligence amplifies the characteristics of both the first and the second levels, while intellectual activity is carried out mainly at an unconscious level, a level that approximates a person to use of automated skills and abilities. The next, the fourth level, is the level of meta-intellectual activity, which explodes the creative achievements of the person. Thanks to this fourth level of intelligence a person is able to establish interaction not only with different objects and other people, but also with the world as a whole, thus expanding the limits of his/her intellect and starting a dialogue with the creative beginning of the world (Fig. 1). 


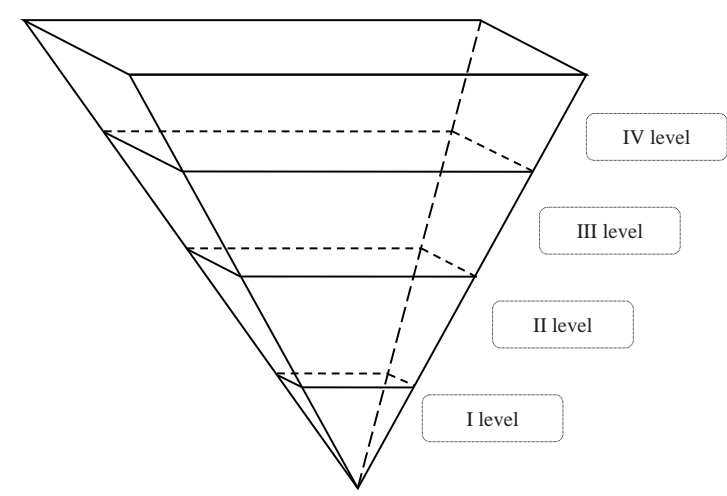

Fig. 1. Intellectual sphere of the person (understanding of intelligence in the broad sense)

Detailed marks:

o the I-st level - the level of functioning of cognitions (mental processes, speech and interaction)

o the II-nd level - the level of metacognitions (intellectual initiation, reflection, decentralization, intellectual strategies and abilities (abilities and competences), metacognitive monitoring, intuition, intellectual attitudes (values, meanings)

$o$ the III-d level - the level of amplification of characteristics of the 1st and the 2nd levels; realization of the intellectual activity at the unconscious level

$o$ the $I V$-th level - the level of providing meta-intelligence activities (explication of individual creative achievements of the person)

When it comes about intelligence in the narrow sense, we rely first of all on the model of the intellect of G. Gardner (Gardner, 1993), which in his recent works distinguishes seven types of intelligence: linguistic intelligence, musical one, logical intelligence and mathematical one, spatial intelligence, physical-kinesthetic one, interpersonal intelligence and intrapersonal one. Such models of intelligence are distinguished by J. Kihlstrom and N. Cantor (Kihlstrom \& Cantor, 2013). In particular, technical intelligence is highlighted in the theories of G.O. Ball and V.O. Medintsev (Ball \& Medintsev, 2011), J. Kihlstrom and N. Cantor (Kihlstrom \& Cantor, 2013). Also, J. Kihlstrom and N. Cantor (Kihlstrom \& Cantor, 2013), E. Fedorova (Fedorova, 2009) singled out poetic and artistic intelligence, G.O. Ball and V.O. Medintsev (Ball \& Medintsev, 2011) - also aesthetic intelligence. The basis of all these models was the peculiarities of the classification of abilities, which authors, as a rule, refer to certain synthesizing factors (for example, the factor that determines the ability of a person to operate on quantitative relationships, the factor determines the ability to qualitative analysis and the formation of categories and classifications). 
That is, each type of intelligence contains certain abilities of the person to perform a certain type of the activity. In this case, for example, «linguistic intelligence» is referred to as «intelligence» by the authors, because it is a complex of integral education, which includes separate abilities to perform a certain type of the activity, and if we talk about a specialist in this sphere of the activity, his/her competences, we remind about the structure of the professional competence of the person.

Thus, guided by the narrow sense of understanding the word «intelligence», we distinguish: social intelligence; technical intelligence; artistic intelligence; information intelligence.

To artistic intelligence we refer the abilities that many authors have attributed to linguistic, poetic, artistic, dance, aesthetic intelligence, because we consider them the abilities of one semantic group. The level of the development of artistic intelligence inevitably determines such qualitative features of thinking as poetry and imaginative thinking. Subjects with a high level of the development of artistic intelligence are characterized by aspirations for new and unknown, lack of fear of risk.

Information intelligence, in our opinion, is related to the development of abilities to work in a complicated information society, to understanding of information systems and networks, to predict their further development and functioning. If we consider information systems as a communication system that assists in collecting, searching, processing and forwarding information, the information intelligence, due to the set of abilities that are part of it, provides some maintenance into the structure of information system. Such abilities are: the abilities, aimed at assessing the situation (solving problems in recognition of images); the abilities aimed at transforming the description of the situation (solving settlement problems, problems in modeling); the ability to make decisions (including optimization).

\section{Methods and methodical instrumentation of the research}

The first phase of the experiment was carried out during 2005. The method of the research at this stage was the observation of teachers of preschool establishments, the selection of methodical tools for empirical research. The second, empirical stage of our study was carried out during 2006-2008. The following methods were used in the research: 
1) general scientific methods (analysis, comparison, generalization); 2) the psychodiagnostic method, which was provided using the test of J. Gilford and M. O'Sullivan «Research of Social Intelligence» (Gilford \& O'Sullivan, 2007), verbal and figurative subtest «Methods of studying divergent thinking» by P. Torrens, J. Gilford (in the modification of O.E. Tunik) (Torrens \& Gilford, 2012); associative experiment (using the method of B.V. Zeygarnik «Understanding the portable value of proverbs and metaphors» (Zeygarnik, 2008); 3) mathematical and statistical methods (statistical estimations of distribution parameters, $\mathrm{x}$-Pearson criterion, checking of statistical hypotheses by means of parametric t-Student's criteria and the non-parametric U-criterion Manna-Whitney, the r-Spearman correlation coefficient).

Also, to determine the psychological type of the teacher's person we used: a questionnaire by V.M. Minyarov (Minyarov, 2009); typographic questionnaire MBTI; personal questionnaire of $\mathrm{CPI}$; a questionnaire for evaluation of personal and business professionalimportant qualities of the person (Bazarov, 2013); a questionnaire for evaluation of interpersonal admissibility (Bahareva, 2005); a questionnaire for evaluation of assessing the complex of productivity in managerial situations (Scock, 2008); the questionnaire proposed by us for the purpose of diagnosing difficulties of interaction of teachers with other people.

Therefore, 114 respondents were evenly distributed in groups:

E1 - 16 teachers of II and III categories (the experience of work from 5 to 10 years, age - up to 30 years) of regional cities (5 respondents of the garden № 2 of Rivne, 5 educators of the garden № 5 of Kharkiv and 6 teachers of the garden № 11 Odessa city, Ukraine);

E2 - 18 teachers of category I (work experience - from 10 to 15 years, age - from 30 to 37 years) of regional cities ( 7 respondents of the garden № 2 of Rivne, 6 teachers of the garden № 5 of Kharkiv and 5 teachers of the garden № 11 Odessa city, Ukraine);

E3 - 15 teachers of the highest category (the experience of work from 15 and more, age - from 37 years) of regional cities (5 respondents of the kindergarten № 2 of Rivne, 5 educators of the garden № 5 of Kharkov and 5 teachers of the garden № 11 of Odessa, Ukraine);

E4 - 13 teachers of category I (work experience - from 5 to 10 years, age - up to 30 years) of regional towns (4 respondents from 
the town of Zdolbuniv of Rivne region, kindergarten № 1; 5 tutors of Shepetovka, Khmelnytskyi region, kindergarten № 2; 4 respondents from the town of Zdolbuniv, Rivne region, kindergarten № 5, Ukraine);

E5 - 14 teachers of II category (the experience of work - from 10 to 15 years, age - from 30 to 37 years) of regional towns (6 respondents in the town of Zdolbuniv of Rivne region, the garden № 1, 4 educators of Shepetivka, Khmelnytskyi region, the garden № 2; 4 respondents from the town of Zdolbuniv, Rivne region, garden № 5, Ukraine);

E6 - 19 teachers of the highest category (work experience from 15 years and more, age - more than 37 years) of regional towns (5 respondents in Zdolbuniv city of Rivne region, kindergarten № 1; 5 educators of Shepetivka town of Khmelnytskyi region, kindergarten № 2; 9 respondents from the town of Zdolbuniv, Rivne region, kindergarten № 5, Ukraine);

E7 - 19 directors of kindergartens (this group includes directors of cities and regional towns, such as: nursery schools № 2 and № 4 of Rivne, nursing homes № 5, 13, 14, 15, 18 of Kharkiv, nursery schools № 3, 8, 9, 11 in Odessa, kindergarten № 1, 2 in Zdolbuniv, Rivne region, nurseries № 1, 2, 4 in town Shepetovka, Khmelnytskyi region, kindergartens № 1, 2, 5 in town Kamenets-Podolskyi, Khmelnytskyi region, Ukraine).

\section{The results of the research and their discussion}

Thus, the ability to know the results of behavior in a given situation, the ability to understand the typical social value of the situation was studied using subtest 1 «History with the completion» (the test of J. Gilford and M. O'Sullivan «Research of Social Intelligence» (Gilford \& O'Sullivan, 2007)). In general, we see that according to the results of factor analysis, the data from respondents of all groups were insufficiently high, mediocre, regardless of the age of respondents, the acquisition of their professionally significant experience and the position of the director of kindergarten. Thus, for E1 teachers, the result for this ability is 0.41 , for the group of educators E2 - 0.45, for the E3-group respondents -0.43 , for the E4-group -0.42 , for respondents from the group E5 - 0.41, groups E6 - 0.40 and, finally, from the directors of kindergartens (group E7) -0.41 . 
Somewhat higher are the results of respondents of all groups on «the ability to learn classes of behavior, to distinguish common essential features in different nonverbal reactions of a person, to generalize social reactions (subtest 2 «Groups' expression» of the test of J. Gilford and M. O'Sullivan «Research of Social Intelligence» (Gilford \& O'Sullivan, 2007)). Thus, the respondents of different groups have such results: in $\mathrm{E} 1-0.50$, in $\mathrm{E} 2-0.55$, in $\mathrm{E} 3-0.54$, in $\mathrm{E} 4-0.53$, in $\mathrm{E} 5-0.51$, in E6 -0.52 , in E7 - 0.50. These results, to our mind, indicate that the educator of the kindergarten formed holistic social perceptual standards that did not foresee the analysis of individual details of objects or subjects, however, this situation greatly enhanced the flexibility of teachers in the sense of nonverbal speech.

According to such abilities as «the ability to learn classes of behavior, to distinguish common essential features in different nonverbal reactions of a person, to generalize social reactions» (subtest 2 «Groups' expression» of the test of J. Gilford and M. O'Sullivan «Research of Social Intelligence» (Gilford \& O'Sullivan, 2007)) and the «ability to understand the meaning of the utterance depending on the context of the situation» (subtest 3 «Verbal expressions» of the test of J. Gilford and M. O'Sullivan «Research of Social Intelligence» (Gilford \& O'Sullivan, 2007)), the results of respondents of all groups are rather mediocre, in general, do not exceed the mark of 0.56. Only in the E7 group (directors of preschool establishments), the «ability to understand the meaning of statements depending on the context of the situation» is slightly higher (0.6813). We consider that the administrative position of the head of pre-school establishments was significantly influenced the level of social Intelligence (high level of it).

Also, the results of teachers of kindergartens and directors of these establishments are rather mediocre for «the ability to understand the systems of behavior, the meaning of situations of interaction in the dynamics» (subtest 4 «Stories which the person has to finish»). Thus, the respondents of groups E1 and E3 have an index of the development of this ability of 0.48 , teachers of group E2 -0.43 , of group E4 -0.54 , in group E5 - 0.53, in group E6 - 0.49, in group E7 - 0.48. Such results also indicate that the development of social intelligence of teachers of pre-school educational establishments is at a rather mediocre level. The composite assessment of the social intelligence of the respondents was also studied by us. The results are: in group E1 -0.50 , in groups E2 
and E3 - 0.51, in groups E4 and E6 - 0.49, in group E5 - 0.48, in group E7 -0.53 . These results indicate a fairly mediocre level of social intelligence among all teachers of preschool educational establishments, including directors who run preschool educational institutions.

At the second stage of the experiment we analyzed the results having been obtained by "Methods of studying divergent thinking» by P. Torrens, J. Gilford (in the modification of O.E. Tunik) (Torrens \& Gilford, 2012). The results according to the subtest «extrapolation of subjective representations in predicting the integral meaning of the situation, the ability to formulate guesses» were quite high in all groups (in group E1 - 0.89, in group E2 - 0.87, in group E3 - 0.84, in group E4 - 0.78, in groups E5 and E7 - 0.82, in group E6 - 0.83).

We mean that high results of teachers of preschool establishments depend on tactical type of thinking, which is realized in forecasting situations, making the details of the plan and predicting conditions for playing role-playing games with children. The result of forecasting is the construction by a teacher a conceptual model of the professional activity, that helps to create a generalized image of situations and actions that are adequate in preschool establishments. We've also emphasize that teachers are involved in game types activities, they better predict the likelihood of more rare event. This is due to the fact that players' games are shaped by the expectation of not only typical but also unexpected events as the tactics of the game are more diverse in comparison with the tactics of conducting a discussion or performing a scenic action (besides teachers themselves and the opponents who are also partners on a team whose positions must be taken into account). Consequently, teachers of preschool educational establishments have the ability to predict incredible situations with a high level of productivity.

Also, so high results are diagnosed in groups of the teachers of pre-school educational establishments for «the success of the generalization of the systems of symbolic units and the ability to build these units into logical structures». We believe that high results of teachers according to this characteristic is in that fact that the success of this subtest is related to the ability to operate the system of values, to reduce them into the whole structures defined by verbal-logical rules directing on constructing the sentences, since the sign has a double ontology: it appears as an instrument of knowledge and means of interaction in the process of communication. It should be noted that, 
based on the results of the observation carried out at the first stage of the experiment, all teachers of kindergartens were creative individuals, they were actively engaged into a space of artistic creativity, music, dance and others. In turn, artistic creativity, developing a figurative perception of the reality, leads to the development of the ability to express more greater differentiation of the external world, taking into account new, symbolic grounds. Consequently, artistic creation involves the structuring of specific, sensory features into a single image-symbol, so we mean the generation of semantic units and the ordering of them into a certain structure getting its development in these conditions of professional activity of the teachers of pre-school educational establishments.

It is important that the main feature of the professional activity of preschool teachers is the significant contribution of social intelligence into the process of cognitive activity. Also we consider the success in the productivity of the semantic generation of ideas based on the operation of a sign system in the connection with a productive communicative activity of respondents within the pre-school educational establishments. The main function of the sign in terms of interaction and communication is to mediate the communicative intention of the subject. The teacher for obtaining the ultimate goal has to reach the goal to create a particular sign in the mind of the recipient, and for this purpose he must do objective the corresponding content inside the context of a real sign. At the same time, in the scientific literature it is noted that there are objective means in the language that turn the combination of words into a holistic, meaningful statement; to one of these means refer the location of the words in the sentence (Fedorova, 2009). In such a way the success of generating understandable according to other statements in terms of pedagogical interaction develops as a structuring and operation of signs based on the developed socio-historical practice of verbal-logical frames.

We'd like to describe the results of the teachers of pre-school educational establishments for «updating the diversity of associations, doing partial categorizations, generalizations, without performing logical operations» (we received these results by Subtest № 3 «Speech Association»).

The results of the teachers of pre-school educational establishments are quite high at this scale. Thus, respondents from group E1 received 0.78 points, from group E2 -0.73 , from group E3 -0.75 , from group 
E4 - 0.79, from group E5 - 0.72, from group E6 - 0.69, from group E7 - 0.68. These high results, we can predict, are due to the fact that, to our mind, the success of respondents of actualization of various individual categorizations is determined by the conditions of art-music and dance activity of teachers of pre-school educational establishments. These results were associated with the understanding of these types of activities as enriching the subject with various sign systems (non-verbal sign system of dance, figurative-symbolic representation system in the artistic creativity). Sign systems, acting instruments of knowledge, determine the ability of the person to the most diverse and bulk actualization of the potential features of the subject.

Also, high results of respondents may be explained by the principle of the activity of the subject in solving different contradictions in the context of the professional activity, which is constantly associated with the organization of children's games, that provides a certain level of the success of updating certain categories and associations. However, the inter-subjective nature of the game limits this ability in the development of the person, which involves subjectivity in the assessment of the situation, so inter-subjective interaction at pre-school educational establishments is influenced on social intelligence in less degree.

The success of the transformation of the uncertain material and the approach of reaching this material to the frames that the subject has in his/her own imagination is investigated by the IV-th subtest «Sketches». The results we've received are also quite high among teachers of pre-school educational establishments. The lowest results were obtained by directors of pre-school educational establishments (0.53). These results show that the success of the transformation of indeterminate material and bringing it to existing ones in the view of the teacher gets its development in conditions of music, artistic and dance activity. High results can be explained from the point of view of the presence of teachers who implement these types of creative activities, a diverse system of subjective representations (based on the results of the research according to the III-d subtest «the ability to update ideas»).

But this ability, which we explore, also includes the procedural aspect as the teacher's ability to correlate and to transform the uncertain material and to give it a definite meaning. Perhaps this aspect of the development of this ability is influenced by the person's need in the reproduction process of correlating the idea according to the result 
the teacher had wished. This result is possessed inside a subject, with objective aesthetic criteria, which are required from the product (musical, artistic and dance activities). These conditions actualize the ability of the person to harmony, the correlation of the sensory, the initial idea of the subject of the activity as an uncertain material and the conditions of doing the objective world, which appear as a mechanism for the explication of a subjective representation, which require the transformation of subjective representations to the paradigm of objective criteria.

Also high results of «the success of the transformation of the uncertain material and the approach of this material to the frames that the subject has in his/her own imagination» to our mind are connected with the fact that the professional activity of a teacher of a preschool educational establishment is based on the operational response in a situation "here and now», in which the dynamics of changes make it possible to solve any problem or a problem that arises suddenly, without pre-ordered tactical decisions. Most of these solutions are relevant at this time, because, as a rule, in a few seconds quite a lot of other actions are required. In other words, this activity does not create the need for the teacher to correlate and to transform the obscure, fuzzy image into a system of fixed values.

We'll analyze the results we obtained for «the success of the synthetic perception and completion of the indefinite object» (using the V-th subtest «A hidden form»). High results of the teachers of pre-school educational establishments of all groups tell us that the respondents who participated in a creative activity were much more successful in completing the unfinished image, even when they were offered an absolutely indeterminate object.

From the standpoint of the activity approach, the dominant image of the actualization of the process of the activity appears not a language, but the specifics of the activity. So we can assume that the high results of teachers of all groups are conditioned by:

a) the relationship of perception and the system of categorization, which are developed in conditions of creative activity (that is musical, artistic activity), in conditions of group forms of work;

b) the influence of the situational factor in the professional activity, which determines the specificity of the perception of the person of the surrounding reality. It should be emphasized that the success of 
the professional activity of teachers of pre-school educational institutions is based on intuitive decisions, which are carried out on the basis of reduced, summarized reasoning due to personally and professionally significant experience, including the experience of the head of preschool educational establishments.

\section{Conclusions}

Consequently, the results obtained by us allow us to draw the following conclusions:

1. The respondents of all groups have the results which show the advantage of average indicators of their ability to understand the meanings of non-verbal expressions and the meaning of the expression, depending on a social context. This may be due to the fact that these abilities are formed in the immediate process of communication and to a large extent depend on the conditions of the life of the subjects, at the first place - on the conditions of their professional activity, means and methods of professional activity of teachers of preschool educational establishments.

2. The indicators of social intelligence, related to the ability to learn the results of the person's behavior in certain situations, combined with knowledge of the systems of the behavior and knowledge of the situations in the dynamics do not have significant differences in the groups of respondents, including the results of directors of preschool educational establishments. Also, there were no significant differences in the results of respondents residing in the oblast or district centers, indicating the independence of the level of social intelligence from the social conditions of teachers' residencies, their age, professional experience, etc., as the respondents with the highest category demonstrated such level of the development of social intelligence, as well as teachers who had only the I-st and the II-d categories.

According to these results, there is no impact of detected residence (saturation with typical cultural and social values), of significant professional experience of the person on the ability to understand the meanings of typical social situations as socio-cultural factors of social intelligence of teachers of preschool educational establishments. The overall indicator of social intelligence in all groups of respondents is 
somewhat lower than the results of the individual abilities of social intelligence, which indicates the compensation of certain skills and abilities through higher levels of others, in particular, as we think - by divergent thinking.

Thus, we highlight the main functions of social intelligence of teachers and directors of preschool educational establishments as «understanding other people», which provides foresight in interpersonal relationships, the effectiveness of understanding of social situation in general and the situations of interpersonal interaction in particular. The function of «adaptation to the requirements of the society» is also dominant. We've to note that this function provides the ability of the person to use psychometric intelligence in order to adapt to the society effectively. The indicator of highly developed social intelligence is the effectiveness of the use of individual metacognitive strategies while performing social tasks and solving various problems.

The next dominant function of social intelligence of teachers and directors of preschool educational establishments is the function of «deep knowledge of the behavior of social objects». This function ensures the ability of the person to communicate with other people, the ability to predict the consequences of other people's behavior; the ability to distinguish essential features in the content of verbal and nonverbal reactions of people; the ability to understand changes in the meaning of verbal and nonverbal reactions of people depending on the context of a particular situation; the ability to understand the logic of the development of the situations of interpersonal interaction, to understand the value of the behavior of other people.

Also we've to underline cognitive and behavioral functions of social intelligence. In particular, the cognitive function involves the assessment of the prospects of the person's development; understanding of people; to provide social insight; knowledge of social norms. Behavioral functions include: the ability to co-operate with other people; social adaptation; empathy in interpersonal relationships.

\section{References}

Ball, G.O., \& Medintsev, V.O. (2011). Osobystist yak indyvidualnyi modus kultury i yak intehratyvna yakist osoby [The Person as an individual mode of culture and as integrative quality of a person]. Horyzonty osvity - Horizons of education 3, 7-14 [in Ukrainian]. 
Bazarov, T.Yu. (2013). Metodika ocenki lichnostno-delovyx professional'no vazhnyx kachestv lichnosti [A questionnaire for evaluation of personal and business professional-important qualities of the person]. Retrieved from mydisser.com/ru/ catalog/view/252/807/ 18233.html [in Russian].

Bakhareva, N.V. (2005). Metodika mezhlichnostnogo prinyatiya (shkala prinyatiya individom gruppy) [A questionnaire for evaluation of interpersonal admissibility)] [in Russian].

Collins, M.X. (2014). Information Density and Dependency Length as Complementary Cognitive Models. Journal of Psycholinguistic Research, 43(5), 651-68. https:// doi.org/10.1007/s10936-013-9273-3

Fedorova, E.A. (2009). Socialnyj intellekt kak faktor formirovaniya otnosheniya k socialno znachimym obektam u predstavitelej razlichnyx etnicheskix grupp [Social intelligence as a factor in the development of attitudes towards socially important objects among representatives of different ethnic groups]. Candidate's thesis. Yaroslavl [in Russian].

Gardner, H.E. (1993). Multiple intelligences: the theory in practice. N-Y.: Basic Books. Guilford, J., \& O'Sulliven, M. (2007). Test «Socialnyj intellekt» [Test «Research of Social Intelligence»]. Retrieved from lib.chdu.edu.ua/pdf/posibnuku/160/41.pdf [in Russian].

Guilford, J.P. (1956). The structure of intellect. N.-Y.: «Psychol Bull».

Kihlstrom, J.F., \& Cantor, N. (2013). Social Intelligence. Retrieved from http:// istsocrates.berkeley.edu/ kihlstrom/social_intelligence.htm

Minyarov, V.M. (2009). Metodika opredeleniya psixologicheskogo tipa lichnosti [A questionnaire for determining the psychological type of the person]. Retrieved from w.psinside.ru/ndos-850-1.html [in Russian].

Skock, R. (2008). Metodika ocenki kompleksnoj produktivnosti v upravlencheskix situaciyax [A questionnaire for evaluation of assessing the complex of productivity in managerial situations]. Retrieved from mydisser.com/ru/catalog/ view/252/807/18233.html [in Russian].

Smulson, M.L. (2003). Psykholohiia rozvytku intelektu v rannii yunosti [Psychology of the development of the intelligence]. Doctor's thesis. Kyiv: Nora-print [in Ukrainian].

Tillman, R., \& Louwerse, M. (2018). Estimating Emotions Through Language Statistics and Embodied Cognition. Journal of Psycholinguistic Research, 47(1), 125-138. https://doi.org/10.1007/s10936-017-9522-y

Torrens, P., \& Guilford, J. (2012). Metodika issledovaniya divergentnogo myshleniya $v$ modyfikatsii O.E. Tunik [Methods of studying divergent thinking in the modification of O.E. Tunik]. Retrieved from https://dytpsyholog.com/ [in Russian].

Zasekina, L.V. (2006). Strukturno-funktsionalna orhanizatsiia intelektu osobystosti [Structural-functional organization of intelligence of the person]. Extended abstract of Doctor's thesis. Kyiv [in Ukrainian].

Zeigarnik, B.V. (2008). Metodika «Ponimanie perenosnogo znacheniya poslovic $i$ metaphor» [A questionnaire "Understanding the portable value of proverbs and metaphors»]. Retrieved from ibib.ltd.ua/ponimanie-perenosnogo-smyislaposlovits-25938 [in Russian]. 


\section{АНОТАЦІЯ}

В статті зазначено, що соціальний інтелект в психології розглядається як здатність людини правильно розуміти свою поведінку і поведінку інших людей у суспільстві. Ця здатність $\epsilon$ вельми необхідною для людини для ефективної міжособистісної взаємодії та успішної соціальної адаптації. Соціальний інтелект реалізує функціонування пізнавальних процесів, пов'язаних із відображенням людини як партнера по спілкуванню та діяльності. Основна фуннкція соціального інтелекту у нього - прогнозування поведінки інших.

Автори статті розглядають поняття «інтелект» в широкому та вузькому смислах слова. У широкому розумінні йдеться лише про один-єдиний інтелект, про інтелектуальну среру особистості тощо. В такому сенсі інтелект особистості описано як ієрархічну систему, яка має декілька рівнів. Перший рівень - рівень функціонування когніцій. Другий рівень інтелекту рівень метакогніцій. Третій рівень інтелекту ампліфікує характеристики як першого, так і другого рівнів, при цьому інтелектуальна діяльність здійснюється переважно на неусвідомлюваному рівні, рівні, який наближує особистість до використання автоматизованих навичок та вмінь. Наступний, четвертий рівень, - рівень метаінтелектуальної діяльності, на якому відбувається експлікація творчих здобутків особистості.

Визначено, що кожен вид інтелекту вміщує певні здібності особистості до виконання певного виду діяльності. Керуючись вузьким розумінням слова «інтелект», у статті виокремлено: соціальний інтелект; технічний інтелект; мистецький інтелект; інформаційний інтелект тощо.

Було описано емпіричне дослідження, в якому брали участь педагоги дошкільних закладів освіти різних регіонів України та директори цих закладів. Доведено, що у респондентів всіх груп виявлено перевагу “середніх» показників за здібностями до розуміння значень невербальної експресії та смислу висловлювання залежно від соціального контексту. Це може бути пов'язано із тим, що дані здібності формуються в безпосередньому процесі спілкування та великою мірою залежать від умов життєдіяльності суб'єктів, в першу чергу від умов професійної діяльності, засобів та способів виконання професійної діяльності педагогів у дошкільних закладах освіти.

Ключові слова: соціальний інтелект, когніції, метакогніції, метаінтелектуальна активність, технічний інтелект, мистецький інтелект, інформаційний інтелект.

\section{Ивашкевич Эдуард, Яцюрик Алла. Психолингвистическое изучение функционирования когниций и метакогниций на уровнях социального интеллекта}

\section{АННОТАЦИЯ}

В статье показано, что социальный интеллект в психологии рассматривается как способность человека правильно понимать своё поведение и поведение других людей в обществе. Эта способность определённо является необходимой 
Психолінгвістичне вивчення функиіонування когніцій...

для человека с целью осуществления эфрфективного межличностного взаимодействия и успешной социальной адаптации в обществе. Социальный интеллект способствует функционированию познавательных процессов, связанных с отражением человека как партнера по общению и деятельности. Основная функция социального интеллекта - прогнозирование поведения других людей.

Авторы статьи рассматривают понятие «интеллект» в широком и узком пониманиях. В широком смысле речь идет об одном единственном интеллекте, об интеллектуальной сорере личности. В этом понимании интеллект личности описано как иерархическую систему, которая имеет несколько уровней. Первый уровень - уровень функционирования когниций. Второй уровень интеллекта - уровень метакогниций. Третий уровень интеллекта амплифицирует характеристики как первого, так и второго уровней, при этом интеллектуальная деятельность осуществляется преимущественно на неосознаваемом уровне, уровне, который приближает личность к использованию автоматизированных навыков и умений. Следующий, четвёртый уровень - уровень метаинтеллектуальной деятельности, на котором происходит экспликация творческих достижений личности.

Определено, что каждый вид интеллекта состоит из определённых способностей личности к выполнению определённого вида деятельности. В соответствии с узким пониманием «интеллекта» в статье выделены: социальный интеллект; технический интеллект; художественный интеллект; информационный интеллект.

Было описано эмпирическое исследование, в котором принимали участие педагоги и директора дошкольных учебных заведений разных регионов Украины. Доказано, что у респондентов всех групп выявлено преимущество "средние» показатели способностей к пониманию значений невербальной экспрессии и смысла высказывания в зависимости от социального контекста. Это может быть связано с тем, что данные способности формируются в непосредственном процессе общения и во многом зависят от условий жизнедеятельности субъектов, в первую очередь - от условий их профессиональной деятельности, средств и способов её выполнения.

Ключевые слова: социальный интеллект, когниции, метакогниции, метаинтеллектуальная активность, технический интеллект, художественный интеллект, информационный интеллект. 